\title{
Effects of the Fiber Percentage RATE OF THE GFPR COMPOSITES
}

\author{
Cavusoglu, I., Walcher E.M., Ugur Tuncer, G. \& \\ DURAKBASA, N.M.
}

Abstract: Today, the first rule of international competition is energy-efficient production for many industry areas. From this point of view, composite is selected materials, which are lighter than metallic materials but also as resistant as in terms of mechanical strength. The composite's products shape could easily be produced with using different primary methods. Drilling is secondary process and then assembly is also necessary to create for manufacturing final product from GFRP.

This study aims at delamination factor and roughness of evaluation in $50 \%$ and $60 \%$ glass fiber for unmodified GFRP. Both of the evaluations have highly importance for assembled part. The parameters affecting of the workpieces are defined and experimental measurements are carried out to develop procedures in order to improve the quality and accuracy of the workpieces and machining processes.

Key words: Surface roughness, Delamination factor, GFRP
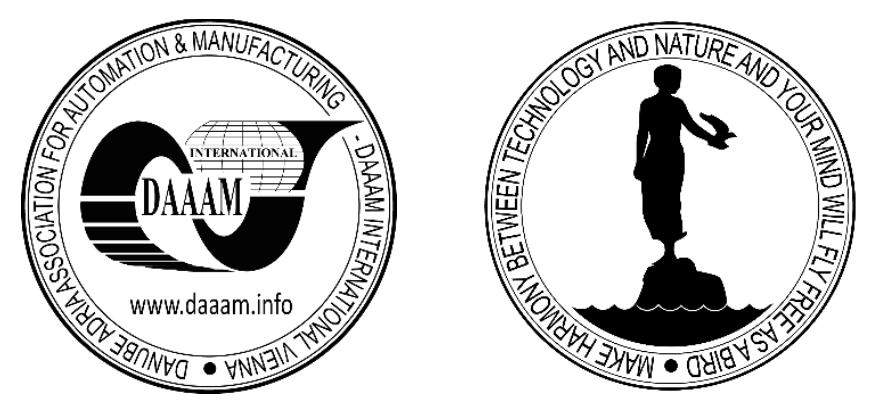

Authors' data: Dr. Sc. Cavusoglu, I[lknur]*; Dipl.-Ing. Walcher, E[va Maria]**; Ugur Tuncer MSc MSc, G[amze]**; Univ.Prof. Dipl.-Ing. Dr.techn. Prof.h.c. Dr.h.c. Durakbasa, N[uman]**; *Marmara University, 34722, Kadiköy/Istanbul, Turkey, **Vienna University of Technology, Karlsplatz 13, 1040, Vienna, Austria, ilknur@marmara.edu.tr, eva.walcher@ift.tuwien.ac.at, aum@ift.tuwien.ac.at, numan.durakbasa@tuwien.ac.at

This Publication has to be referred as: Cavusoglu, I[gnur]; Walcher, E[va] M[aria]; Ugur Tuncer, G[amze] \& Durakbasa, N[uman] (2016). Effects of the Fiber Percentage Rate of the Gfpr Composits, Chapter 30 in DAAAM International Scientific Book 2016, pp.335-342, B. Katalinic (Ed.), Published by DAAAM International, ISBN 9783-902734-09-9, ISSN 1726-9687, Vienna, Austria

DOI: $10.2507 /$ daaam.scibook.2016.30 
Cavusoglu, I.; Walcher, E. M.; Ugur Tuncer, G. \& Durakbasa, N.: Effects of the Fi...

\section{Introduction}

Today, the customer demands that direct the companies, in addition to quality, cost and speed, include environmental factors and energy efficiency and renewable. As the importance of these concepts increase, corporates that possess environmental friendly technology and approaches, also emphasizing energy saving. It is a current perspective to select materials which are lighter than metallic materials but also as durable as in terms of mechanical strength, in addition to design aspects. In the light of this perspective, composite materials have been used widespread in many industry fields.

From a designer and engineering point of view, composites can be produced in large part size and have main features having complex part shape, obtaining the surface shape with multiple compound and excellent structural properties (high strength) e.g. Application of composites brings key advantages lightweight high corrosion strength, high dielectric strength, low thermal conductivity, dimensional stability, low mould investment compared to its cost, and the fact that final product does not require surface treatment e.g. (Aricasoy, 2016; PAGEV, 2016).

Nowadays, applications of the GFRPs and other similar composite materials are founded frequently in many industrial areas aviation, defence, home appliances and business equipment, building industry, consumer goods, sports, entertainment, corrosion resistant products, electrical and electronics industry, marine, transportation and automotive, military applications, agriculture and food sector e.g. In this regard, applications in aeronautics are aircraft and helicopter bodies, cargo containers, wings, propellers, whereas in the transport sector the typical applications are founded within the context of body parts, truck haulages, shafts, truck cabs, vehicle doors, body panels, brake and clutch linings (ISWA, 2016; UEST, 2015).

Several successful applications of composites in the last half-century demonstrate the value of this interesting material. These applications prove the cost and performance value of composites. Furthermore, composites offer advantages unlimited moulding sizes, a great number of production technologies, the possibility of selfcolorization, optionally, being able to be produced as transparent (Usta \& Sipka, 2015; PlasticsEurope, 2016).

It is necessary for a product to have performance and design advantages against its competitors in order to find customers in the market that it is launched in. The aforementioned advantages explain the cause of increasing use of composite materials very clearly. In addition to these properties, a product has also to be cost and energy efficient and environmental-friendly in order to survive within the context of industry (Bas et al., 2015).

There is some kind of problems on the fibre reinforced plastics (FRP) after drilling which is one of secondary process and it is possible to define the problems by using various techniques (Kumar, 2015).

Vankanti et al., 2014 investigated how cutting speed, feed point angle and chisel edge as process parameters effected on the thrust force, torque and circularity of the hole in drilling of GFRP composites. Rubio et al., 2008 studied the delamination factor comparing between the conventional $(\mathrm{Fd})$ and adjusted (Fda) delamination on GFRP. 
Shyha et al., 2009 evaluated thrust force, torque, tool life and delamination of exit and entry on CFRP by using Taguchi L12 matrix with ANOVA. Tsao et al., 2012 developed a comprehensive analysis for delamination caused by eccentric twist drill and eccentric candle stick drill in machining of composite materials. Hocheng et al., 2006 investigated drilling of GFRP to examine correlation between the drillinginduced delamination and thrust force. Tsao, 2012 studied on delamination of CFRP composites by using Response Surface Methodology (RSM) based on Taguchi (L18 orthogonal array) method. Palanikumar, 2011 worked on GFRP composite materials by using the Taguchi's method with Grey Relational Analysis for evaluating performance characteristics such as thrust force, surface roughness and delamination factor.

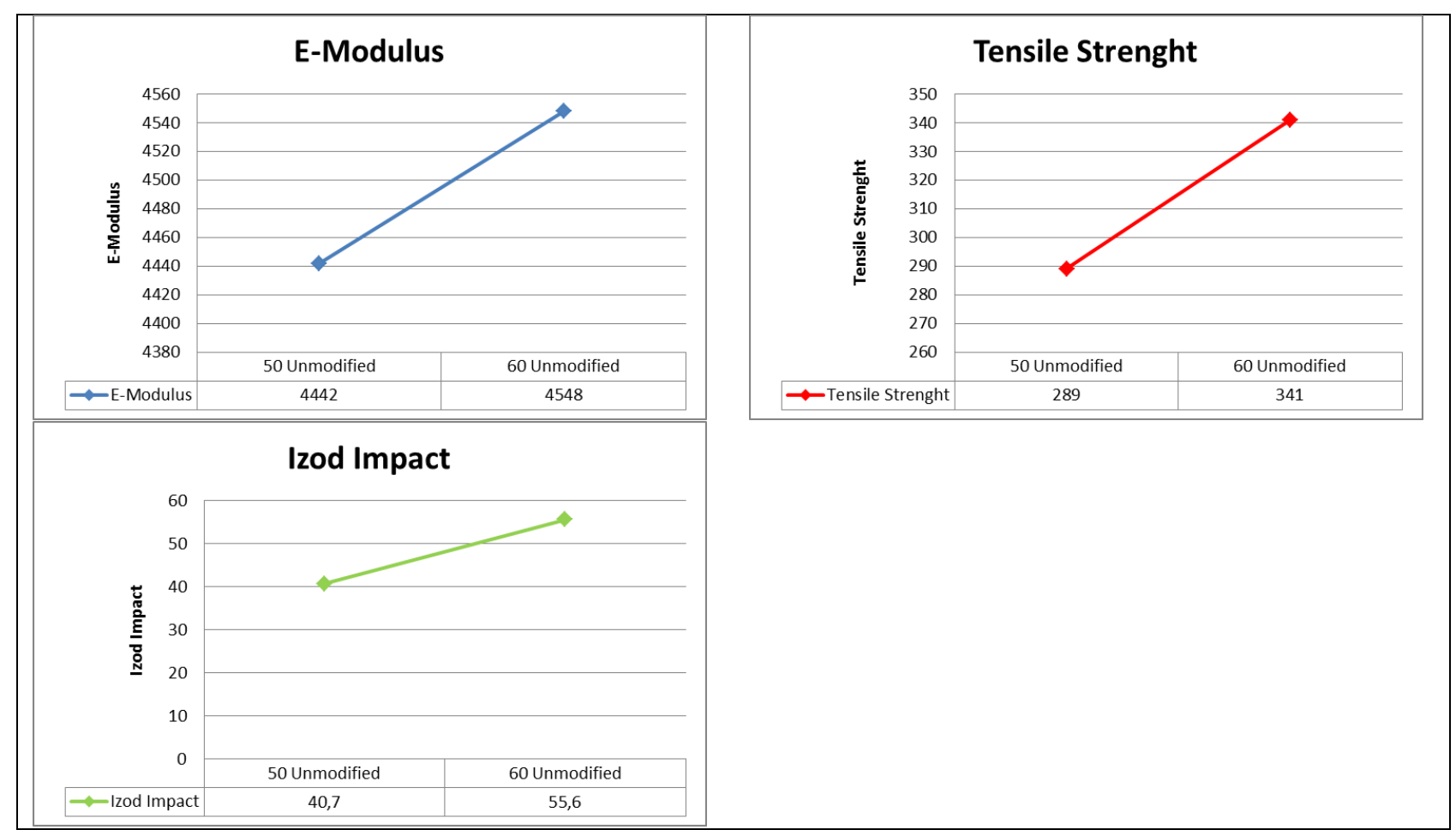

Fig. 1 Mechanical properties of $50 \%$ and $60 \%$ unmodified GFRP

\section{Experimental Study}

In this study, both $50 \%$ and $60 \%$ GFRP composited are unmodified materials. Matrix material contains with epoxy resin, hardener, as an accelerator benzyl dimethylamine (BDMA). Vacuum Assisted Resin Transfer Moulding (VARTM) produced them at room temperature. The tensile strength of the composite decreased with surface modification by APTES but that decreasing can be neglected due to the sound contribution of the delamination. It is shown in figure. 1 mechanical properties of both materials.

Taguchi method was performed to determine the optimal drilling parameters for delamination factor and roughness of GFRP materials. Experimental design was created according to orthogonal array for $50 \%$ and $60 \%$ unmodified GFRP work pieces. The parts were drilled according to L18 matrix, which was designed with Taguchi's design experiment for four different factors (surface condition (A), drill 
Cavusoglu, I.; Walcher, E. M.; Ugur Tuncer, G. \& Durakbasa, N.: Effects of the Fi... diameter (B), spindle speed (C), feed rate (D)), by CNC machine. Taguchi's experiment scheme for 4 factors, one factor two level and three factors three level, is figured in table 1 for L18 matrix and measured responses data.

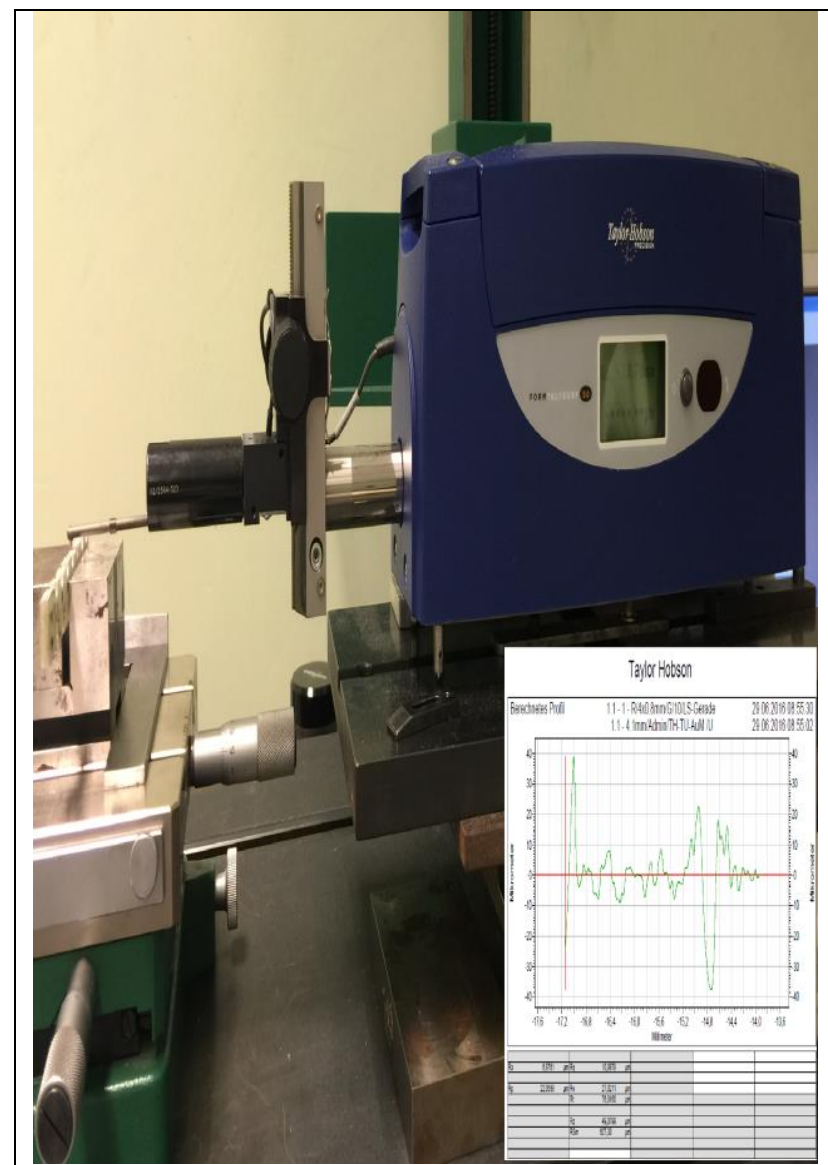

a) The roughness measurement view

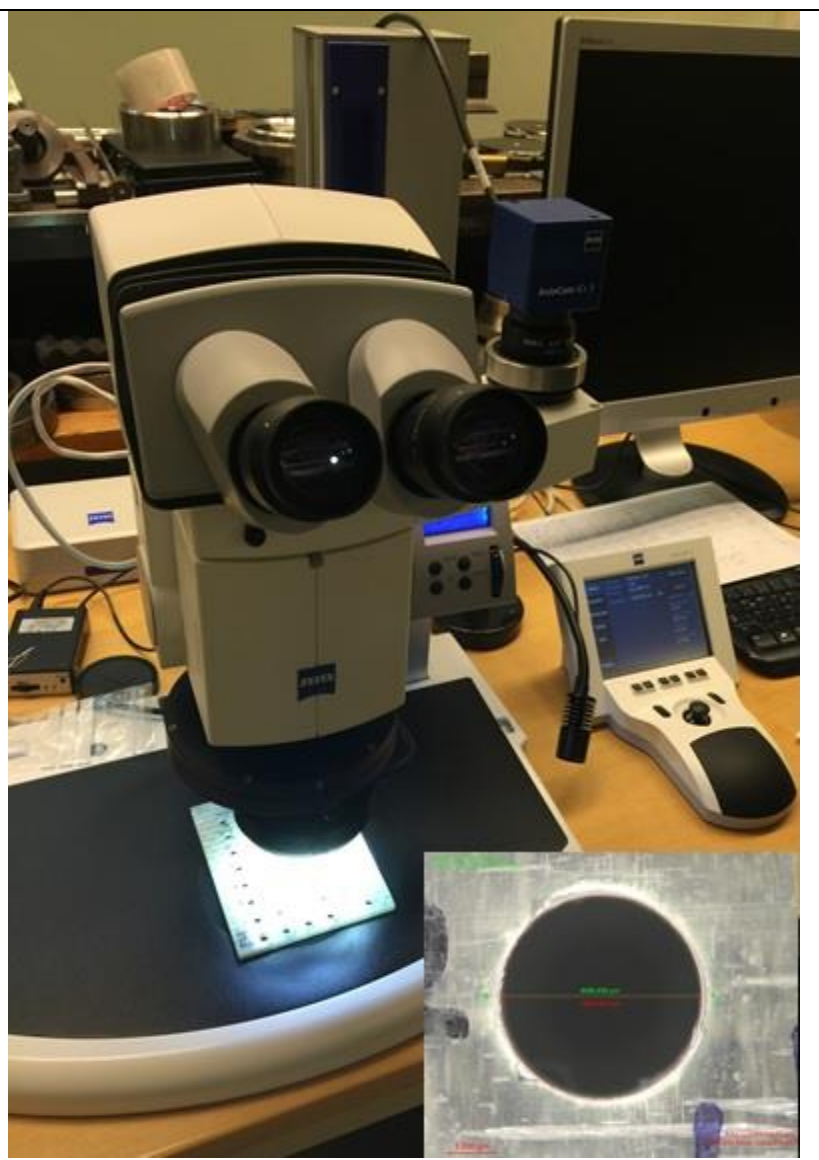

b) The delamination measurement view

Fig. 2 The roughness and the delamination measurement view

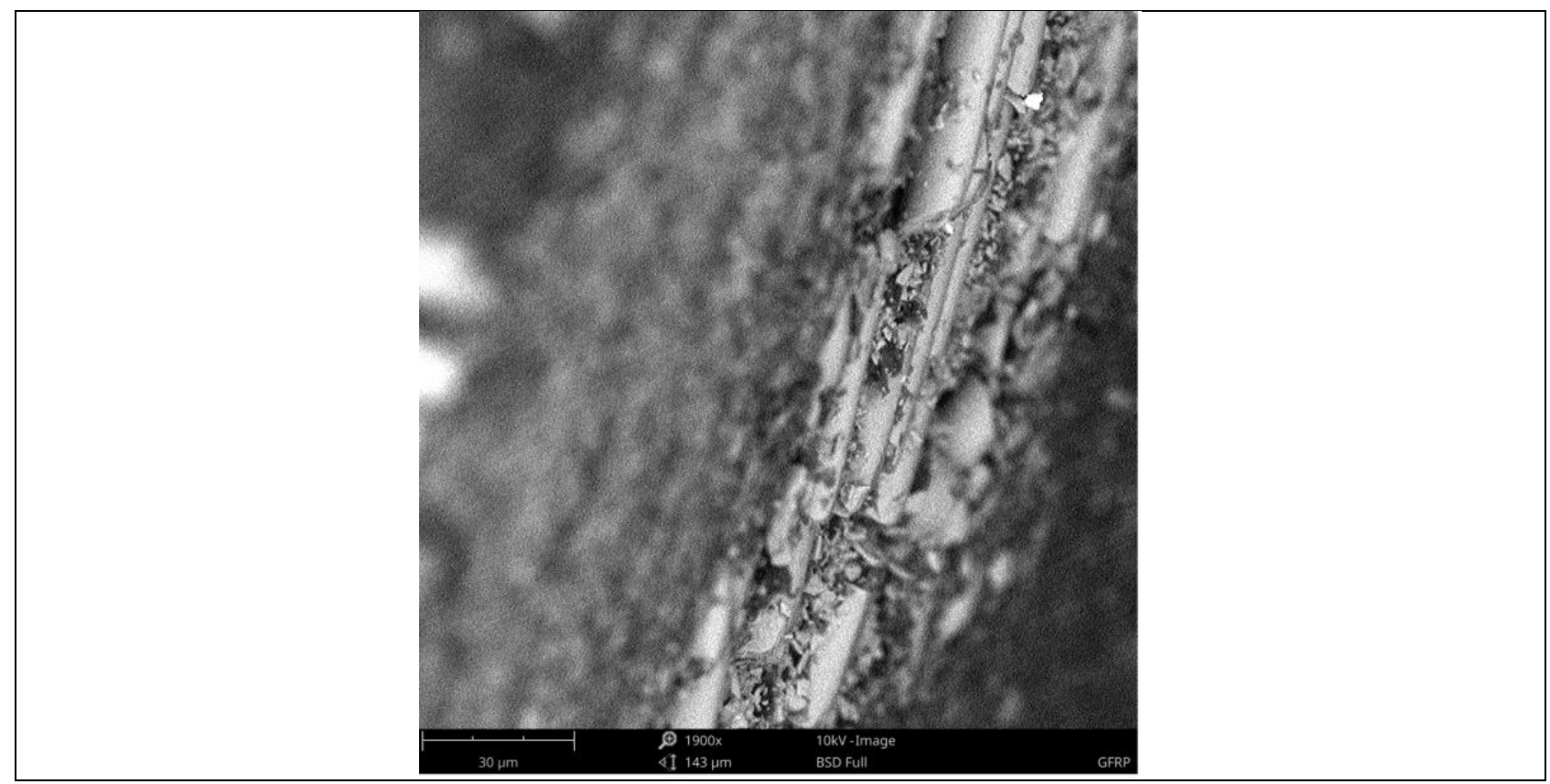

Fig. 3 The hole's inside view 


\begin{tabular}{|c|c|c|c|c|}
\hline & Factors and Levels & chining Parameters) & & \\
\hline & $\mathrm{A}$ & $\mathrm{B}$ & $\mathrm{C}$ & $\mathrm{D}$ \\
\hline Experiment Number & Surface Condition & Drill Diameter $(\mathrm{mm})$ & Spindle Speed (rpm) & $\begin{array}{ll}\begin{array}{l}\text { Feed } \\
(\mathrm{mm} / \mathrm{min})\end{array} & \text { Rate } \\
\end{array}$ \\
\hline 1 & TiN (1) & $4(1)$ & $2000(1)$ & $240(1)$ \\
\hline 2 & TiN (1) & $4(1)$ & $2800(2)$ & $480(2)$ \\
\hline 3 & TiN (1) & $4(1)$ & \begin{tabular}{|l|}
$3600(3)$ \\
\end{tabular} & $720(3)$ \\
\hline 4 & TiN (1) & $5(2)$ & $2000(1)$ & $240(1)$ \\
\hline 5 & TiN (1) & $5(2)$ & $2800(2)$ & $480(2)$ \\
\hline 6 & TiN (1) & $5(2)$ & $3600(3)$ & $720(3)$ \\
\hline 7 & $\operatorname{TiN}(1)$ & $6(3)$ & $2000(1)$ & $480(2)$ \\
\hline 8 & TiN (1) & $6(3)$ & $2800(2)$ & $720(3)$ \\
\hline 9 & TiN (1) & $6(3)$ & $3600(3)$ & $240(1)$ \\
\hline 10 & Uncoated (2) & $4(1)$ & $2000(1)$ & $720(3)$ \\
\hline 11 & Uncoated (2) & $4(1)$ & $2800(2)$ & $240(1)$ \\
\hline 12 & Uncoated (2) & $4(1)$ & $3600(3)$ & $480(2)$ \\
\hline 13 & Uncoated (2) & $5(2)$ & $2000(1)$ & $480(2)$ \\
\hline 14 & Uncoated (2) & $5(2)$ & $2800(2)$ & $720(3)$ \\
\hline 15 & Uncoated (2) & $5(2)$ & $3600(3)$ & $240(1)$ \\
\hline 16 & Uncoated (2) & $6(3)$ & $2000(1)$ & $720(3)$ \\
\hline 17 & Uncoated (2) & $6(3)$ & $2800(2)$ & $240(1)$ \\
\hline 18 & Uncoated (2) & $6(3)$ & $3600(3)$ & $480(2)$ \\
\hline
\end{tabular}

Tab. 1 Taguchi's L18 experiment matrix.

\begin{tabular}{|c|c|c|c|c|c|c|c|c|c|c|c|c|}
\hline \multicolumn{13}{|c|}{ Responses } \\
\hline \multirow{3}{*}{$\begin{array}{l}\text { Exp. } \\
\text { No } \\
\end{array}$} & \multicolumn{6}{|c|}{$50 \%$ UnModified } & \multicolumn{6}{|c|}{$60 \%$ UnModified } \\
\hline & \multicolumn{3}{|c|}{ Surface Roughness $\left(\mathrm{R}_{\mathrm{a}}\right)$} & \multicolumn{3}{|c|}{ Delamination Factor } & \multicolumn{3}{|c|}{ Surface Roughness $\left(\mathrm{R}_{\mathrm{a}}\right)$} & \multicolumn{3}{|c|}{ Delamination Factor } \\
\hline & 1 & 2 & 3 & 1 & 2 & 3 & 1 & 2 & 3 & 1 & 2 & 3 \\
\hline 1 & 4,62171 & 4,4087 & 5,3303 & 1,1314 & 1,1351 & 1,1455 & 5,2854 & 4,4911 & 5,3540 & 1,1934 & 1,1977 & 1,2067 \\
\hline 2 & 2,0677 & 2,0115 & 3,3163 & 1,6691 & 1,2246 & 1,2522 & 3,9659 & 3,3663 & 3,3852 & 1,2291 & 1,1410 & 1,5053 \\
\hline 3 & 2,4403 & 2,0333 & 2,0270 & 1,2134 & 1,4938 & 1,2788 & 2,3440 & 2,5201 & 2,6786 & 1,3590 & 1,2715 & 1,2088 \\
\hline 4 & 2,7332 & 2,5430 & 3,1298 & 1,18 & 1,1208 & 7 & 3,8033 & 4,0385 & 4,5292 & 1 & 2721 & 3302 \\
\hline 5 & 2,4172 & 2,3084 & 2,1038 & 1,1636 & 1,2542 & 1,2628 & 2,6082 & 3,1158 & 5,8807 & 1,1448 & 1,1277 & 1,1915 \\
\hline 6 & 2,1159 & 4,4461 & 4,7513 & 1,2604 & 1,2207 & 1,1986 & 3,2340 & 3,5868 & 5,7969 & 2520 & 1,1108 & 1,1641 \\
\hline 7 & 2,8452 & 3,1165 & 2,3755 & 1,2063 & 1,6325 & 1,1937 & 2,2067 & 2,2210 & 2,5247 & 1,1412 & 1,1364 & 1,1588 \\
\hline 8 & 3,3539 & 2,6220 & 3,3662 & 1,4481 & 1,2748 & 1,5844 & 3,1858 & 2,4972 & 2,9875 & 1,1201 & 1,5513 & 1,1783 \\
\hline 9 & 4,0342 & 3,5379 & 3,7591 & 1 , & 1, & 1,3860 & 3,4984 & 3,6688 & 3,8413 & 1317 & 705 & 1,0702 \\
\hline 10 & 3,4721 & 3,3329 & 3,2368 & 1,7038 & 1,3044 & 2,3665 & 8,6738 & 8,5400 & 7,4746 & 2,3290 & 2,0342 & 1,3271 \\
\hline 11 & 2,1719 & 2,0251 & 5,4974 & 1,1759 & 1,0571 & 1,1892 & 7,7398 & 8,6334 & 8,0430 & 1,1513 & 1,1107 & 1,2107 \\
\hline 12 & 2,6139 & 4,0507 & 4,2454 & 1,1637 & 1,1509 & 2,2617 & 8,3441 & 6,6604 & 7,1196 & 1,2082 & 1,1921 & 1,1695 \\
\hline 13 & 3,1867 & 2,5420 & 4,0182 & 1,6692 & 1,2878 & 1,8166 & 3,0788 & 3,5077 & 2,9646 & 1,4756 & 1,8544 & 1,1511 \\
\hline 14 & 3,1372 & 3,1653 & 4,6269 & 1,7357 & 1,8000 & 1,7714 & 4,1666 & 4,0597 & 4,9864 & 1,1473 & 1,1428 & 1,3652 \\
\hline 15 & 3,2645 & 4,3505 & 4,3663 & 1,1121 & 1,0633 & 1,1653 & 4,6096 & 4,1084 & 4,7897 & 1,0936 & 1,0810 & 1,0772 \\
\hline 16 & 3,4933 & 3,7752 & 5,1702 & 1,8514 & 1,2597 & 1,4038 & 1,9918 & 1,5237 & 2,0250 & 1,4873 & 1,1576 & 1,2504 \\
\hline 17 & 2,1961 & 1,9251 & 3,0112 & 1,1093 & 1,1800 & 1,1962 & 1,9910 & 1,6223 & 1,6593 & 1,1375 & 1,1529 & 1,0865 \\
\hline 18 & 2,6695 & 3,8442 & 5,9772 & 1,1871 & 1,1184 & 1,1090 & 3,7951 & 5,8780 & 8,0379 & 1,1225 & 1,1191 & 1,3973 \\
\hline
\end{tabular}

Tab. 2. L18 Matrix with measured responses data.

Each experiment was repeated three times. Spindle speed from 2000 to 3600 (rpm) and feed rate from 240 to $720(\mathrm{~mm} / \mathrm{min})$ were selected as machining parameters. Drilling 
Cavusoglu, I.; Walcher, E. M.; Ugur Tuncer, G. \& Durakbasa, N.: Effects of the Fi...

tools surface condition TiN and uncoated HSS and drill diameter from 4 to $6(\mathrm{~mm})$ were chosen as the other factor of experiment. All tests run without coolant liquids.

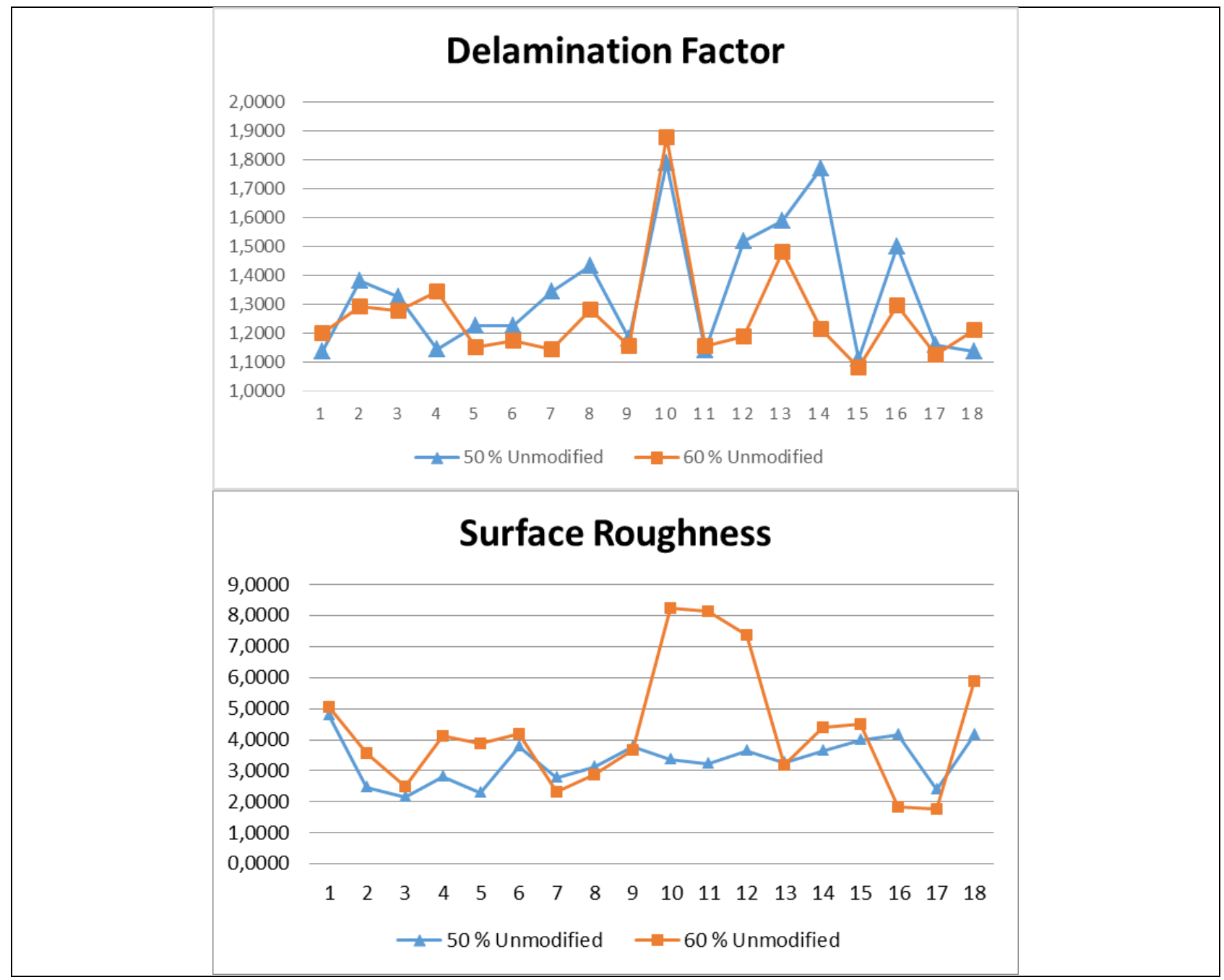

Fig. 3 Delamination factor and Surface roughness of $50 \%$ and $60 \%$ unmodified GFRP

$50 \%$ and $60 \%$ unmodified GFRPs' were drilled by Awea BM-1020 CNC machining center. This machine could operate (work) 1500 - $8000 \mathrm{rpm}$ spindle speed and 1 $10000 \mathrm{~mm} / \mathrm{min}$ cutting feed rate. The measurements were made by Zeiss SteReo Discovery V20 microscope, which was equipped to PlanApo S 1.0x $60 \mathrm{~mm}$ objective and Zeiss AxioCam Icc 5 camera. Magnification of the microscope characterized with the properties is maximum 150x and its maximum resolution is $2,33 \mu \mathrm{m}$. In this study, all the holes and the damage around the holes were measured with 13x magnification. The surface roughness was measured by Form Talysurf 50 (DIN EN ISO 4287, 2010). Figure 2 is showed a roughness and a delamination measurement view and devices. The hole's inside view was examined Phenom Prox, desktop SEM (scanning electron microscope). The microscope's light optical magnification is $20-135 \mathrm{X}$ and electron optical magnification range $80-130000 \mathrm{X}$ and its maximum resolution is less than 10 $\mathrm{nm}$. Figure 3 is showed that there was some broken glass fiber in the inside of the holes. It is demonstrated that hypervariable surface roughness could be got in its inside. 


\section{Result}

Figure 3 was denoted that the lowest delamination value was seen on the hole which was drilled with uncoated $5 \mathrm{~mm}$ drill bit and the highest spindle speed (3600 $\mathrm{rpm})$ and the lowest feed rate $(240 \mathrm{~mm} / \mathrm{min})$ delamination factor for both materials. On the other side, the highest delamination was occurred on hole whose drilling parameter were uncoated $4 \mathrm{~mm}$ drill bit and lowest spindle speed $(2000 \mathrm{rpm})$ and highest feed rate $(720 \mathrm{~mm} / \mathrm{min})$. The same drilling parameter was showed the lowest surface roughness for both $50 \%$ and $60 \%$ unmodified GFRP. When looking at both the delamination and roughness values for $50 \%$ and $60 \%$ fiber rate unmodified parts in table 2 , there was noticeable variety between two materials values. Changing fiber rate of part significantly decreased on delamination and roughness in figure 3 . If the composite material's fiber rate was changed, both delamination factor and roughness showed different effect in the study. This was an important contrast for product life circle and performance of GFRP parts which was assembled. Taking into account the different effect of the evaluated factor also decreases the number of materials, which goes to waste before the assembly. If the life cycle of the product increases it will make less damage on the environment.

\section{Conclusion}

Delamination factor and surface roughness are investigated using experimental design's factors on both $50 \%$ and $60 \%$ fiber percentage on GFRP. The experimental factors are surface condition, drill diameter, spindle speed and feed rate.

The following conclusion is got according to this study:

1. When delamination factors are evaluated on holes drilled with different parameters, the values of delamination on $50 \%$ fiber percentage material are higher than the other rate of fiber in $78 \%$ percent of the obtained data.

2. When surface roughness is researched on the same holes, the roughness on the $50 \%$ fiber percentage material is lower than the $60 \%$ rate.

3 . There is opposite relationship between delamination factor and surface roughness on fiber rate percent change.

4. Both delamination and roughness have an effect on assembled product life cycle.

5. On the design phase, it is important that materials selection is carefully made a choice by taking into account the mechanical properties of these materials.

\section{Acknowledgements}

This research is partially supported within the scope of TUBITAK 2219. All measurements and evaluation processes of this study were carried out at Vienna University of Technology, Nanotechnology Laboratory of the Department for Interchangeable Manufacturing and Industrial Metrology at the Institute for Production Engineering and Laser Technology. 
Cavusoglu, I.; Walcher, E. M.; Ugur Tuncer, G. \& Durakbasa, N.: Effects of the Fi...

\section{References}

Aricasoy, O. (2016). Kompozit Sektor Raporu: http://www.ito.org.tr/Dokuman/ Sektor/1-57.pdf: 2016

Bas, G.; Durakbasa, N. M.; Mankova, I. \& Vrabel, M. (2015). An innovative approach of metrology for high precision and quality maching tool assessment in the integrated production engineering, 26. Daaam International Symposium on Intelligent Manufacturing and Automation, 2015, pp. 787-794.

DIN EN ISO 4287, (2010). Geometrical Product Specifications (GPS) - Surface texture: Profile method - Terms, definitions and surface texture parameters.

Hocheng, H. \& Tsao C. C. (2006). Effects of special drill bits on drilling-induced delamination of composite materials, International Journal of Machine Tools \& Manufacture, Vol: 46, 2006, pp. 1403-1416

ISWA, (2016). A Roadmap for Closing Waste Dumpsites The World's Most Polluted Places: http://www.iswa.org/uploads/tx_iswaknowledgebase/Pico_Bartl.pdf: 2016 Kumar, S. (2015). Drilling of fibre reinforced plastics (FRPs) Materials: A literature survey, International Journal of Composite and Constituent Materials, Vol: 1, Issue: 1, 2015, pp.14-32

PAGEV, (2016). http://www.pagev.org.tr/admin./PICS/dosyalar/-Turkiye_Otomotiv Plastikler_2010_Yili_Sektor_Raporu.pdf: 2016-06-01

Palanikumar, K. (2011). Experimental investigation and optimization in drilling of GFRP composites, Measurement, Vol: 44, 2011, pp. 2138-2148

Plastics Europe, (2016). Introduction to Fibre Reinforced Plastics (FRP): http://plasticeurope.org/Documents/Document/20100602173200-

CEFICArticle1 Introductionto UPRdraft2-20060306-008-EN-v1.pdf: 2016-05-15

Rubio J. C.; Abrao A. M.; Faria P. E.; Correia A. E. \& Davim J. P. (2008). Effect of high speed in the drilling of glass fibre reinforced plastic: Evaluation oft the delamination factor, International Journal of Machine Tools\&Manufacture, Vol: 48, 2008, pp. 715-720

Shyha, I. S.; Aspinwall D. K.; Soo S. L. \& Bradley S. (2009). Drill geometry and operating effects when cutting small diameter holes in CFRP, International Journal of Machine Tools \& Manufacture, Vol: 49, 2009, pp. 1008-1014

Tsao, C. C. \& Hocheng H. (2005). Effect of eccentricity of twist drill and candle stick drill on delamination in drilling composite materials, International Journal of Machine Tools \& Manufacture, Vol: 45, 2005, pp. 125-130

Tsao, C. C. (2012). Evaluation of the drilling-Induced delamination of compound corespecial drills using response surface methodology based on the Taguchi method, International Journal of Advanced Manufacturing Technology, Vol: 62, 2012, pp. 241247

UEST, (2015). http://uest.ntua.gr/conference2014/pdf/ribeiro_et_al.pdf: 2015-03-15

Usta, R. \& Sipka, T. (2015) Polimerik Kompozit Sektorunde Standartlar: http://www.kmo.org.tr/resimler/ekler/b57994eec3c2a37_ek.pdf: 2015-03-15

Vankanti, V. K. \& Ganta, V. (2014). Optimization of process parameters in drilling of GFRP composite using Taguchi method, Journal of Materials Research and Technology; Vol: 3, Issue: 1, 2014, pp. 35-41 